Vasyl POROKHNYA, Oleksandr OSTAPENKO

\title{
MODEL OF ALLOCATION \\ OF BUDGET AND BORROWED FUNDS \\ FOR THE ARMED FORCES \\ OF UKRAINE DEVELOPMENT PROGRAMS IN COMPLIANCE WITH NATO STANDARDS
}

\begin{abstract}
The AFU support budget policy does not have any sufficient modern mechanism for the best budget planning, which would predict the possible state of budget items execution and resolve the alignment of financial processes to NATO standards. And this is caused by the lack of application of particular mathematical tools for budgetary processes prediction and optimization to carry out the evaluation and analysis of the budget use considering the probability factor.

A model for managing the use of budget and borrowed funds for the Armed Forces of Ukraine development programs according to NATO standards, considering the levels of long-term development of programs and the probability of their implementation, is developed.
\end{abstract}

(C) Vasyl Porokhnya, Oleksandr Ostapenko, 2018.

Porokhnya Vasyl, Doctor of Economics, Professor, Classic Private University, Zaporizhzhia, Ukraine. Ostapenko Oleksandr, Senior Lecturer, Military Institute of Kyiv National Taras Shevchenko University, Ukraine. 
456 V a s y I P o r o k n y a, O I e k s a d r o s t a p e nk o Model of Allocation of Budget and Borrowed Funds for the Armed Forces of Ukraine Development Programs in Compliance with NATO Standards

The result of the evaluation of the Armed Forces of Ukraine effectiveness based on the utility function and cognitive model was the management model for the processes of budget and borrowed funds use for the AFU development programs in compliance with NATO standards. The model takes into account the long-term programs development levels and the probability of their implementation, affecting the interaction between the indicators of the AFU planning and budget process execution and increasing the effectiveness of defense reform in Ukraine. Its practical use helps to approach NATO standards in budgetary sphere and provides an opportunity to forecast budget under expenditures under the risk of its use.

The cognitive model of the impact of interaction between the planning and the AFU budget process execution indicators on the effectiveness of defense reform in Ukraine establishes the links in the contours of the defense reform effectiveness management, which can be defined as critical, i. e. risky and provides an opportunity to assess the risk levels of each contour and to model scenarios and options for improving the processes of planning and use of budget funds for defense reform.

The decrease of the Armed Forces of Ukraine budget underfunding initially leads to a vibrational process of impacts on the target vertex, but then the process stabilizes.

In order to study the dynamics of influence of the factors, acting as instruments of the AFU budget resources management on the target vertex, apply the method of impulse processes. This method is used for scenario modeling of alternative decisions.

\section{Key words:}

Model, budget program, budgetary risk, the Armed Forces of Ukraine, N A model for managing the use of budget and borrowed funds for the Armed Forces of Ukraine development programs according to NATO standards, considering the levels of long-term development of programs and the probability of their implementation, is developed.

JEL: E69. 


\section{Problem setting}

The Ukrainian state has permanently suffered from political, economic and military oppression from its neighboring states throughout its existence from ancient times till the present. It is still unclear whether it is the geographical location being determined as the center of Europe, or the ineffective leadership has always forced Ukraine to uphold its legitimate interests, territorial integrity and independence. Considering the conditions, the Armed Forces of Ukraine (the AFU) are the cornerstone to protecting the territorial integrity and inviolability of Ukraine entrusted to them by the Constitution of the state.

Now, it is the first time in the recent history of Ukraine that the AFU budget has been increased almost in 3-4 times since 2014. But, in general terms, the ratio of expenditures to GDP (see Table 1) does not comply with the Law of Ukraine on National Security of Ukraine adopted in June 21, 2018, where under Article 35 «the amount of expenditures for financing the security and defense sector has to be at least five per cent of the planned gross domestic product, of which not less than three percent are intended to finance the defense forces».

Table 1

Financial support for the Ministry of Defense of Ukraine (MOD) during 2009-2018

\begin{tabular}{|c|c|c|c|}
\hline Years & GDP, bln UAH & $\begin{array}{c}\text { Expenditures } \\
\text { on the MOD, } \\
\text { bln UAH }\end{array}$ & $\begin{array}{c}\text { \% of MOD } \\
\text { expenditures } \\
\text { from GDP }\end{array}$ \\
\hline 2009 & 913 & 8,3 & 0,91 \\
\hline 2010 & 1083 & 10,2 & 0,95 \\
\hline 2011 & 1314 & 12,3 & 0,94 \\
\hline 2012 & 1409 & 14 & 1 \\
\hline 2013 & 1455 & 13,9 & 0,96 \\
\hline 2014 & 1567 & 26,5 & 1,69 \\
\hline 2015 & 1979 & 49,3 & 2,49 \\
\hline 2016 & 2262 & 55,9 & 2,47 \\
\hline 2017 & 2845 & 69,2 & 2,43 \\
\hline 2018 & 3332 & 86,6 & 2,6 \\
\hline
\end{tabular}


458 V a s y I P o r o k h y a, o I e k s a n d r o s t a p e nk o Model of Allocation of Budget and Borrowed Funds for the Armed Forces of Ukraine Development Programs in Compliance with NATO Standards

However, numerous negative factors of influence, both external and internal, pose threats of the existing financial budget risks in the Armed Forces of Ukraine and absolutely new ones, provoking multiple financial and material losses. Considering the difficult financial situation of the state, the priority task today is to prevent such losses in the state armed forces through the use of effective, the AFU adapted methods that have gained practical experience in NATO states. Mathematical methods and models for possible risks identification and evaluation while allocating funds for the Armed Forces of Ukraine development programs have been recently widely used in the process of budget resources planning.

\section{Analysis of the recent research}

The concept of risks in the budgetary sphere is framed in the works of such scholars as A. Pavlenko, A. Lukashev, I. Andriievska, T. Kovalchuk, and T. Kovaliov. But these works are not enough for today. Despite the budget sphere is not so interesting for research, it is still rather problematic. The the scientific works of S. Bulhakov (Bulhakova, 2010; Bulhakova, Mykytiuk, 2010), V. Fedosov (Fedosov, 2012, 871 p.), V. Vitlinskii (Vitlinskii, 2004, 480 p.), L. Donets (Donets, 2006, 312 p.), K. Sovietova (Sovietova, 2012, No. 3, pp. 12-16.), I. Blank (Sovietova, 2012, No. 3, pp. 12-16.), F. Sahaniuck (Sahaniuk, Kovalenko, Holubieva, No. 2(48), 2013. pp. 108-113), Dejan Stojkovic and Bjørn Robert Dahl (Dejan Stojkovic, Bjørn Robert Dahl, 28 February 2007, 46 p.) are also dedicated to the peculiarities of budgetary risks definition. However, it should be mentioned that the majority of scientific studies in the area are, as a rule, limited to the research of possible risks arising at the macro level of the state.

\section{The previously unsolved part of the general problem}

The AFU support budget policy does not have any sufficient modern mechanism for the best budget planning, which would predict the possible state of budget items execution and resolve the alignment of financial processes to NATO standards. And this is caused by the lack of application of particular mathematical tools for budgetary processes prediction and optimization to carry out the evaluation and analysis of the budget use considering the probability factor. 
The study objective is to develop a model for managing the use of budgetary and borrowed funds for the Armed Forces of Ukraine development programs in accordance with NATO standards.

\section{Presentation of the main research}

One of the most important places among the risks of the revenue budget is the risk of the special fund filling, defined by the Armed Forces of Ukraine as the main financial plan of the state. Planned revenues from financial and economic activity have in recent years occupied a prominent place in the entire structure of the AFU financial resources. Actual revenues to the special fund from the economic activity of the armed forces have shown that the target figures in some years have been fulfilled scarcely by half over the past five years (2008: $62.9 \%$ of the plan, 2009: $14.11 \%$ of the plan, $2010-31,50 \%$ of the plan, $2011-50,43 \%$ of the plan, $2012-51,63 \%$ of the plan, $2013-89,07 \%$ of the plan, $2014-93,11 \%$ of the plan, $2015-316.98 \%$ exceeding the plan, $2016-68.98 \%$ of the plan, $2017-145.00 \%$ of the plan), Table 2 .

Table 2

State of the Ministry of Defense of Ukraine special fund financial targets performance, mIn. UAH

\begin{tabular}{|c|c|c|c|c|}
\hline \multirow{2}{*}{ Years } & \multicolumn{4}{|c|}{$2010-2017$} \\
\cline { 2 - 5 } & PLAN & FACT & Shortfall & Performance rate, $\%$ \\
\hline 2010 & 2664,00 & 839,20 & 1824,80 & 31,50 \\
\hline 2011 & 2209,60 & 1114,30 & 1095,30 & 50,43 \\
\hline 2012 & 2216,50 & 1144,40 & 1072,10 & 51,63 \\
\hline 2013 & 981,10 & 873,90 & 107,20 & 89,07 \\
\hline 2014 & 1473,60 & 1372,00 & 101,60 & 93,11 \\
\hline 2015 & 819,60 & 2598,00 & $-1778,40$ & 316,98 \\
\hline 2016 & 4520,00 & 3117,70 & 1402,30 & 68,98 \\
\hline 2017 & 6327,40 & 9180,50 & $-2853,10$ & 145,00 \\
\hline 2018 & 4379,90 & - & & \\
\hline
\end{tabular}


Taking into account the fact that while projecting the financial resources for the needs of the Armed Forces of Ukraine, the planned expenditures for specific purposes are formulated from the planned flow of funds to the special fund, then, as a result, we have a lack of particular measures financing, and this leads to a failure to implement the effective output indicators of budget programs.

The economic tools of the AFU budget policy mechanism, as a rule, include the following:

1) budget revenues structure optimization;

2) budget expenditures structure optimization;

3) changes in the inter-budgetary relations policy;

4) budget deficit and state credit.

Today, expenditures on state defense are carried out through budget programs, accumulating the system of quantitative and qualitative indicators, which influence the achievement of the implementation of tasks, entrusted to the Ministry of Defense of Ukraine.

However, according to the data in the Table 3, the AFU financing structure does not correspond to the world practice of allocating the budget for the programs of the Ukrainian security and defense sectors development. Moreover, the funding levels for defense of the neighboring states greatly exceed the budget of the Ministry of Defense of Ukraine. This is vividly proved by the defense budget of Poland, comprising 10 billion euros, not to mention the NATO membership of the state.

Table 3

Armed Forces Financing Structure

\begin{tabular}{|l|c|c|c|c|c|c|}
\hline $\begin{array}{c}\text { Armed Forces } \\
\text { Financing } \\
\text { Structure }\end{array}$ & $\begin{array}{c}\text { World } \\
\text { practice, } \\
\%\end{array}$ & $\begin{array}{c}2010 \\
\text { Ukraine, } \\
\%\end{array}$ & $\begin{array}{c}2016 \\
\text { Ukraine, } \\
\%\end{array}$ & $\begin{array}{c}2017 \\
\text { Ukraine, } \\
\text { bln. UAH } \\
/ \%\end{array}$ & $\begin{array}{c}2018 \\
\text { Ukraine, } \\
\text { bln. UAH/ } \\
\%\end{array}$ & $\begin{array}{c}2018 \text { Po- } \\
\text { land, \% } \\
\text { of } 10 \text { bln } \\
\text { Euro }\end{array}$ \\
\hline $\begin{array}{l}\text { Maintenance } \\
\text { of the Armed } \\
\text { Forces }\end{array}$ & 50 & 87,9 & 79 & $52,2 / 75$ & $60,36 / 70,2$ & 75 \\
\hline $\begin{array}{l}\text { Upgrading } \\
\text { of armaments } \\
\text { and military } \\
\text { equipment }\end{array}$ & 30 & 5,1 & 16,2 & $14,6 / 21$ & $19,5 / 22,7$ & 7 \\
\hline $\begin{array}{l}\text { Armed Forces } \\
\text { training }\end{array}$ & 20 & 7 & 4,8 & $2,67 / 4$ & $2,85 / 3,3$ & 18 \\
\hline
\end{tabular}



follows:

The Armed Forces of Ukraine receive budget funds for the programs, as

1. "Command and control of the Armed Forces of Ukraine» budget program

2. «The Armed Forces of Ukraine maintenance and training» budget program

3. «Medical treatment, rehabilitation and sanatorium support of the Armed Forces of Ukraine personnel, military service veterans and members of their families, and war veterans» budget program

4. «Military specialists training in higher educational establishments, professional development and retraining of military specialists and civil servants, initial military training and patriotic education of youth» budget program

5. «Development, procurement, modernization and repair of armaments, military equipment, tools and facilities» budget program

6. "Construction (purchase) of housing for the Armed Forces of Ukraine servicemen» budget program

7. «Disposal of ammunition, rocket fuel liquid components, armaments, military equipment and other military property, ensuring survivability and explosion and fire protection of arsenals, bases and warehouses of the Armed Forces of Ukraine» budget program

The need to create an effective AFU budget resources managing system results from the significantly increased risk of the lack of funds in different levelbudgets and the risk of underfunding under the conditions of market economy and armed hostilities to protect the country's territory. Therefore, the so-called «budget risk» situation often arises. Budget risk management is a system of risk assessment and market analysis, management of risks and budgetary relations arising in the process of this management. It covers the strategy and tactics of managerial actions for the allocation and execution of budget programs items.

The defense planning models analysis shows that they are, as a rule, based on external risks assessments, pursuant to the defense policy mission, Figure 1. In order to evaluate them, mathematical methods of the alternatives scenario approach, forecasting, identification, and decision making are used. However, they were, unfortunately, used only for the state general defense issues and were not sufficiently applied in the risk assessment of both planning and execution of budget programs. (Sahaniuk, Kovalenko, Holubieva, No. 2(48), 2013. pp. 108-113)

Order of the Ministry of Defense of Ukraine No. 610 dated November 17, 2016 "On Approval of the Provision on Mid-Term and Short-Term Defense Planning in the Ministry of Defense of Ukraine and the Armed Forces of Ukraine»; Dejan Stojkovic and Bjørn Robert Dahl, 28 February 2007, online resource). Midterm defense planning is carried out considering all the changes in the military- 

of Ukraine Development Programs in Compliance with NATO Standards

political situation, real and potential military threats, scenarios and situations with the use of the Armed Forces of Ukraine. The necessary capacities, need for resources, composition, structure and strength of the Armed Forces of Ukraine in peace and war times are also determined (specified) for this purpose (Sahaniuk, Kovalenko, Holubieva, No. 2(48), 2013. pp. 108-113; 8).

During the implementation of short-term defense planning, the previously adopted decisions on implementation of measures for the maintenance and development of the Armed Forces of Ukraine in accordance with the requirements of the State Target Defense Development Program are refined, and the following documents are prepared annually (Sahaniuk, Kovalenko, Holubieva, No. 2(48), 2013. pp. 108-113):

\section{Annual national programs;}

2. Military-political instructions of the Minister of Defense of Ukraine; the Order on defense planning; Proposals to the preliminary indicators of the State Budget of Ukraine draft for the next year, Forecast of expenditures for two subsequent years and changes to the budget programs list;

3. An indicative maintenance and development plan; the MOD budget request; the MOD proposals for the draft of the state defense order basic indicators for the relevant period;

4. Maintenance and development plan; plans for the maintenance and development of armed services; reports on the implementation of short-term planning activities over the past period.

Short-term defense planning process requires military-political situation analysis and definition of the level of military threat to the national security of Ukraine; definition of the AFU development goals (strategic and operational); definition of the development goals (strategic and operational) for scientific and scientific and technical activity in the military sphere; elaboration and monitoring of the relevant state programs (including target ones) and plans implementation; the Ministry of Defense of Ukraine budget request preparation; elaboration of the state defense order main indicators in accordance with the needs, requirements and priorities determined by the General Staff of the Armed Forces of Ukraine (Sahaniuk, Kovalenko, Holubieva, No. 2(48), 2013. pp. 108-113).

Due to the medium and short-term defense planning, the Armed Forces of Ukraine receive a set of decisions in the form of forecasts, programs and plans for the implementation of state policy in the field of defense, given the economic capabilities of the state (Sahaniuk, Kovalenko, Holubieva, No. 2(48), 2013. pp. 108-113); Order of the Ministry of Defense of Ukraine No. 610 dated November 17, 2016 «On Approval of the Provision on Mid-Term and Short-Term Defense Planning in the Ministry of Defense of Ukraine and the Armed Forces of Ukraine»; Dejan Stojkovic and Bjørn Robert Dahl, 28 February 2007, online resource). 


\section{Figure 1}

The general planning process on the basis of capabilities and situational analysis of threats

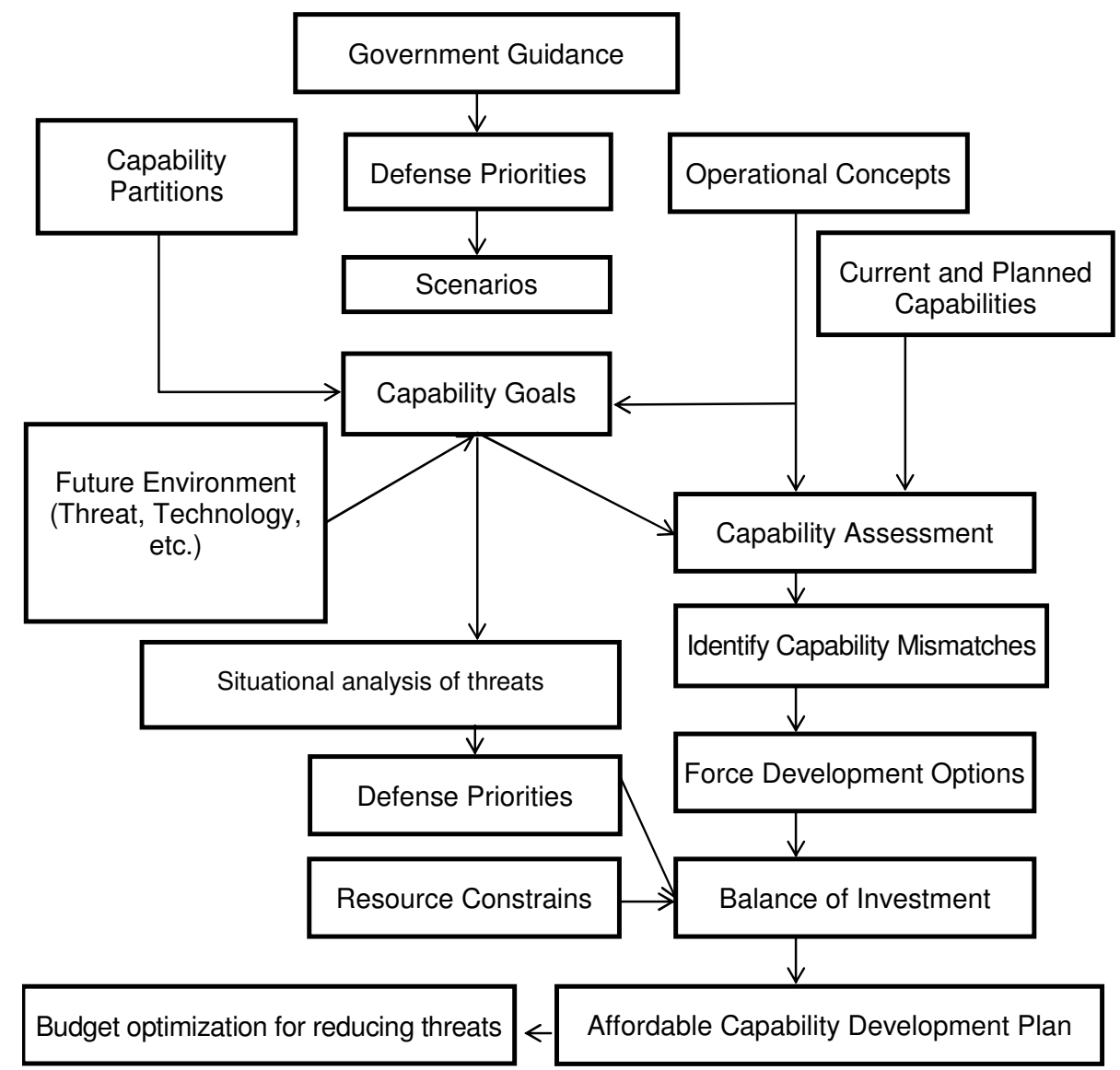

Source: synthesized by authors on the basis of source processing (Dejan Stojkovic and Bjørn Robert Dahl, 28 February 2007, online resource).

Consequently, the studies of these processes and the direction of the methods and models application in the planning and implementation of the defense budget process include the use of mathematical methods and models, among which methods of program-targeted planning and projection, scenarios expert assessment, decision-making, etc. are the most widespread. 
464 V a s y I P o r o k h n y a, O I e k s a n d r O s t a p e nk o Model of Allocation of Budget and Borrowed Funds for the Armed Forces of Ukraine Development Programs in Compliance with NATO Standards

Therefore, there appeared a new conceptual approach to constructing a model to optimize the allocation and projection of use of budget funds for the programs of the AFU development on the basis of the abovementioned factors and measures to minimize budget risks. Now, this approach is the main tool of decision-making on forecasting the ways of using budget funds for the programs of the Armed Forces of Ukraine development, Figure 2.

Figure 2

Conceptual approach to constructing a model for optimization of allocation and projection of use of budget and borrowed funds for the AFU development programs according to NATO standards

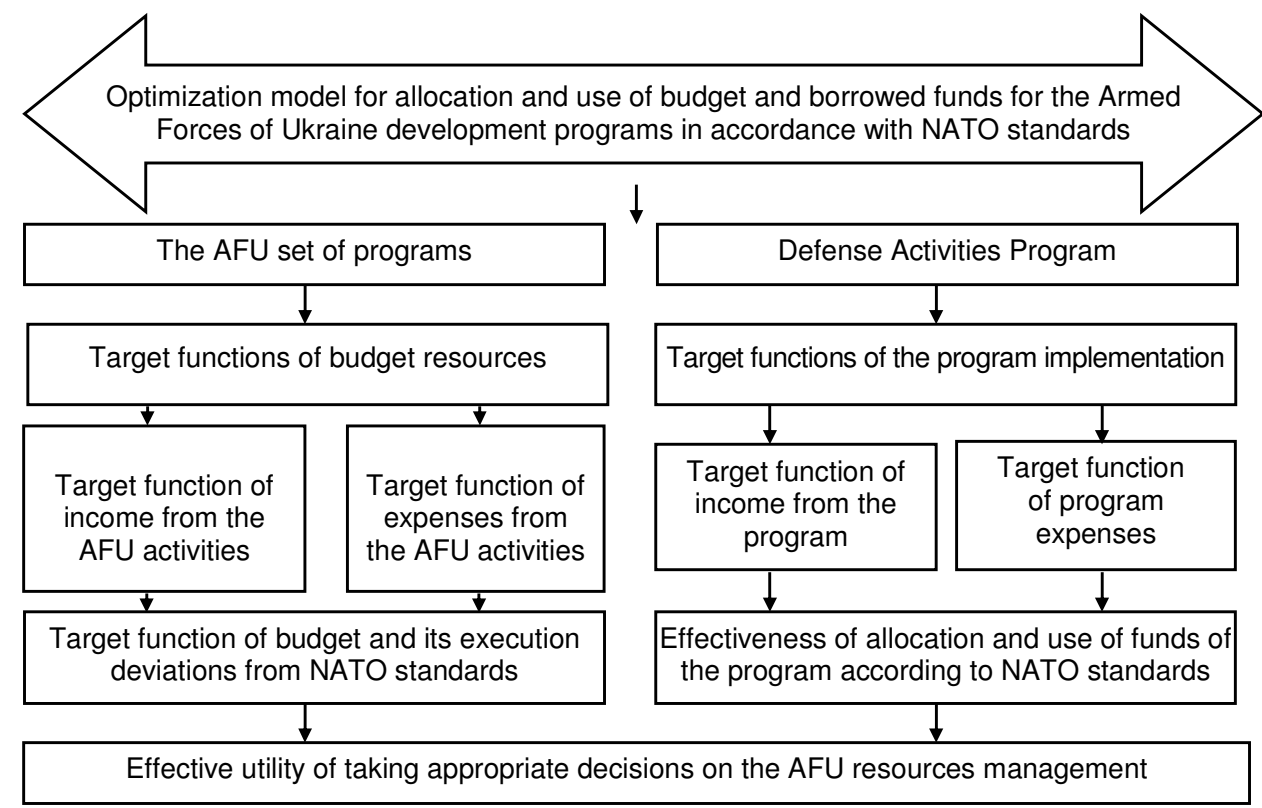

The main focus of the conceptual approach to constructing a model for optimization of allocation and projection of use of budget funds for the AFU development programs is the gradual programming of budgetary funds, taking into account the levels of under expenditures of their use in the Armed Forces of Ukraine activities. To this end, one needs to compare the relevant indicators of 
the revenue and expenditure part of the budget, which can be adjusted due to the particular constraints on both growth and decline of financial resources.

A functional model for constructing a model for managing the processes of budget and borrowed funds use for the AFU development programs according with NATO standards is presented in Figure 3.

Figure 3

Functional model for constructing a model for optimization of allocation and use of budget funds for the Armed Forces of Ukraine development programs in conditions of economic instability

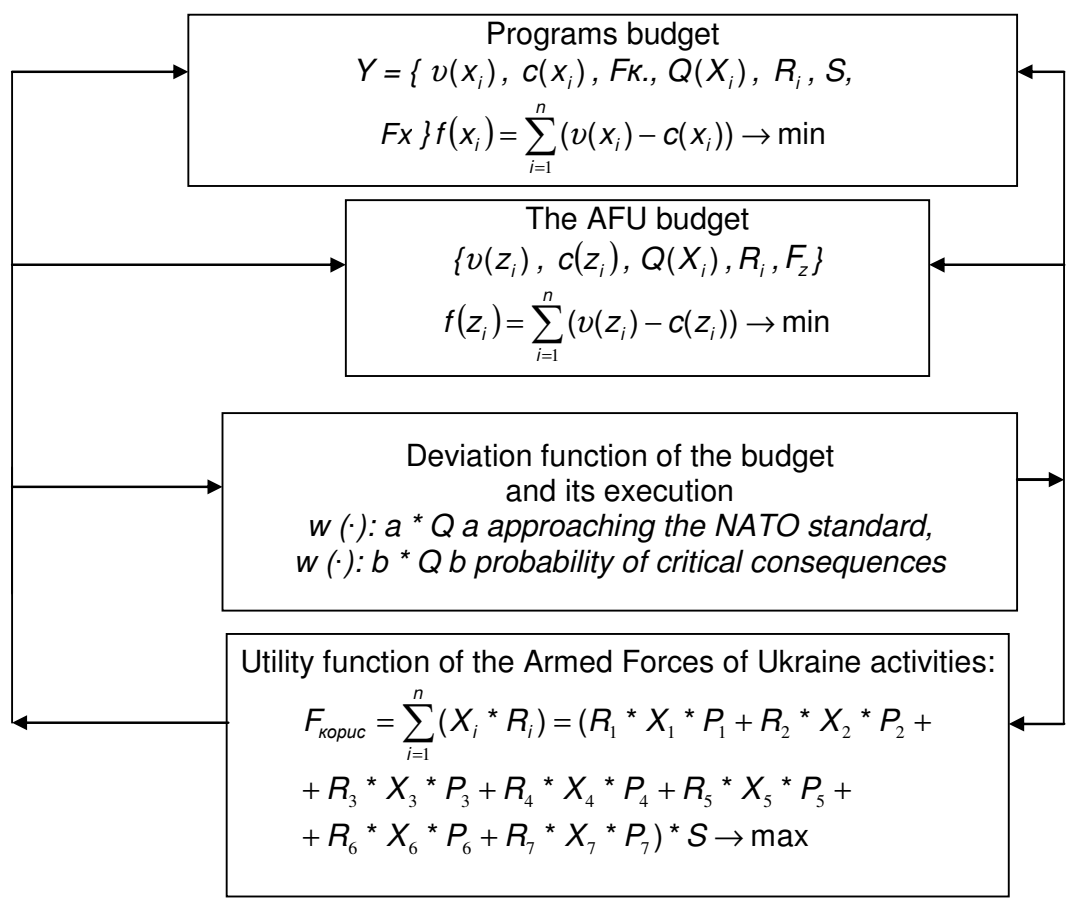

According to the essence of the functional model, it should be noted that the target execution function $x_{i}$ of the program is defined as the difference between the amount of budget resources $v\left(x_{i}\right)$ it receives from allocating the 
budget and revenues from the special fund, and the expenses from the budget items execution through the use of budget funds according to the program:

$$
f\left(x_{i}\right)=\sum_{i=1}^{n}\left(v\left(x_{i}\right)-c\left(x_{i}\right)\right) \rightarrow \min ,
$$

where $c\left(x_{i}\right)$ is the expenditures function while executing $i$-the item of the budget program.

It is similar to the target function $z_{i}$ of expenditures from the AFU activities programs implementation:

$$
f\left(z_{i}\right)=\sum_{i=1}^{n}\left(v\left(z_{i}\right)-c\left(z_{i}\right)\right) \rightarrow \min
$$

where $c\left(z_{i}\right)$ is the expenditures function while executing $i$-the item of the budget program.

The efficiency of the allocation and use of funds under the program is one of the criteria for the effective utility of taking appropriate decisions on the AFU resources management, indicated by the utility function that suggests how effectively the budget funds from programs were allocated and estimates the deviation of budget items execution from the planned data. The model is based on the principles of activating the AFU activities in different particular programs, taking into account the stimulating factor of the special fund growth and considering NATO standards when allocating the budget.

Thus, the AFU activity function within the limits of the budgetary funds use, considering the critical consequences, which is aimed at maximizing the utility function, is presented, as follows:

$$
F_{\text {корис }}=\sum_{i=1}^{n} R_{i}{ }^{*} X_{i}{ }^{*} P_{i}{ }^{*} S \rightarrow \max ,
$$

Where $S=\frac{X^{\text {Special }}}{X^{\text {Total }}}$ is the ratio of the special fund to the general fund;

$R_{i}$ is the AFU budget programs' non-fulfillment risk level.

Restrictions on the programs budgets allocation $\sum_{i=1}^{N} Q\left(X_{i}\right)$ : 


$$
Q_{i \min } \leq \sum_{i=1}^{N} Q\left(X_{i}\right) \leq Q_{i \max },
$$

Where $Q_{i \min }$ is the minimum value of the program funding within the last year;

$Q_{i \max }$ is the maximum value of the program funding within the budget of the program development;

$$
\begin{gathered}
52000<X_{1}<0,4 Q_{i \max }, \\
2100>X_{2}>0,2 Q_{i \max }, \\
140>X_{3}>0,02 Q_{i \max }, \\
1900>X_{4}>0,03 Q_{i \max }, \\
750>X_{5}>0,05 Q_{i \max }, \\
6300>X_{6}>0,3 Q_{i \max }, \\
X 1+X 2+X 3+X 4+X 5+X 6<Q_{i \max } .
\end{gathered}
$$

Limitation of the expenditures planning function under the execution of $i$-the program budget item of the budget allocation according to NATO standards:

$$
\sum_{i=1}^{N} v\left(x_{i}\right) \leq F x .
$$

Limitation of the expenditures planning function under the execution of $i-$ the program budget item according to the budget allocation:

$$
\sum_{i=1}^{M} v\left(z_{i}\right) \leq F_{z} .
$$

Limitations on $S$ which is the ratio value of the program special fund to its general fund:

$$
X_{\min } \leq \frac{X^{\text {Special }}}{X^{\text {Total }}} \leq X_{\max }
$$

Where $X_{\max }$ is the maximum ratio of the special fund to the total budget of the AFU budget program financing;

$X_{\min }$ is the minimum ratio of the special fund to the total budget of the AFU budget program financing, which indicates the previous years of the Armed Forces of Ukraine activities funding. 
Limitation of the execution function $X$ - the program for the cost estimate of $i$ - the program budget item according to the budget allocation in the middle of the program:

$$
a_{i}{ }^{*} w\left(x_{i}\right) \leq c\left(x_{i}\right) \leq b_{i}{ }^{*} w\left(x_{i}\right),
$$

where $w\left(x_{i}\right)$ is the financial limitations of the budget item; $a_{i}, b_{i}$, are the weights of the budget items.

Funding and execution of $x_{i}$-the program for the AFU development under the conditions of economic instability are supported by variable optimization indicators.

Consequently, we get a conceptual approach to constructing a model for optimization of allocation and projection of ways to use budget funds for the Armed Forces of Ukraine development programs. Using the model, we will search for the appropriate solutions regarding the efficiency of allocation and use of funds under the AFU development programs.

Table 4 presents the initial data for optimizing the allocation and use of budget funds for the Armed Forces of Ukraine development programs and the initial data for modeling the effectiveness of planning and using the AFU budget resources.

Table 4

Initial data to optimize the allocation and use of budget funds for the Armed Forces of Ukraine development programs

\begin{tabular}{|l|c|c|c|c|c|c|}
\hline $\begin{array}{c}\text { Name in accor- } \\
\text { dance with de- } \\
\text { partmental and } \\
\text { program classifi- } \\
\text { cation of expendi- } \\
\text { tures and credits } \\
\text { of the state } \\
\text { budget }\end{array}$ & $\begin{array}{c}2016 \\
\text { Total, } \\
\text { ths. UAH }\end{array}$ & $\begin{array}{c}2017 \\
\text { Total, } \\
\text { ths. UAH }\end{array}$ & $\begin{array}{c}2018 \\
\text { General } \\
\text { fund } \\
\text { ths. UAH }\end{array}$ & $\begin{array}{c}2018 \\
\text { Special } \\
\text { fund } \\
\text { ths. UAH }\end{array}$ & $\begin{array}{c}2018 \\
\text { Total, } \\
\text { ths. UAH }\end{array}$ & S \\
\hline $\begin{array}{l}\text { Ministry of De- } \\
\text { fense Ukraine }\end{array}$ & 55627929,4 & 64027400 & 81689208,0 & 1625292,0 & 83314500,0 & 0,02 \\
\hline $\begin{array}{l}\text { Command and con- } \\
\text { trol of the Armed } \\
\text { Forces of Ukraine }\end{array}$ & $\mathrm{R} 1$ & 384518,7 & 495099,6 & 4800,0 & 499899,6 & 0,01 \\
\hline $\begin{array}{l}\text { The Armed } \\
\text { Forces of Ukraine } \\
\text { maintenance and } \\
\text { training }\end{array}$ & $\mathrm{R} 1$ & 51863368,0 & 59265196,4 & 770410,0 & 60035606,4 & 0,01 \\
\hline
\end{tabular}




\begin{tabular}{|c|c|c|c|c|c|c|}
\hline $\begin{array}{l}\text { Name in accor- } \\
\text { dance with de- } \\
\text { partmental and } \\
\text { program classifi- } \\
\text { cation of expendi- } \\
\text { tures and credits } \\
\text { of the state } \\
\text { budget }\end{array}$ & $\begin{array}{c}2016 \\
\text { Total, } \\
\text { ths. UAH }\end{array}$ & $\begin{array}{c}2017 \\
\text { Total , } \\
\text { ths. UAH }\end{array}$ & $\begin{array}{l}2018 \\
\text { General } \\
\text { fund } \\
\text { ths. UAH }\end{array}$ & $\begin{array}{c}2018 \\
\text { Special } \\
\text { fund } \\
\text { ths. UAH }\end{array}$ & $\begin{array}{c}2018 \\
\text { Total, } \\
\text { ths. UAH }\end{array}$ & S \\
\hline $\begin{array}{l}\text { Medical treatment, } \\
\text { rehabilitation and } \\
\text { sanatorium sup- } \\
\text { port of the Armed } \\
\text { Forces of Ukraine } \\
\text { personnel, military } \\
\text { service veterans } \\
\text { and members of } \\
\text { their families, and } \\
\text { war veterans }\end{array}$ & R4 & 1923930,5 & 2160680,7 & 222468,6 & 2383 149,3 & 0,10 \\
\hline $\begin{array}{l}\text { Military specialists } \\
\text { training in higher } \\
\text { educational estab- } \\
\text { lishments, profes- } \\
\text { sional develop- } \\
\text { ment and retrain- } \\
\text { ing of military } \\
\text { specialists and } \\
\text { civil servants, ini- } \\
\text { tial military train- } \\
\text { ing and patriotic } \\
\text { education of youth }\end{array}$ & $\mathrm{R} 2$ & 2106928,3 & 2707018,2 & 140000,0 & 2847018,2 & 0,05 \\
\hline $\begin{array}{l}\text { Development of } \\
\text { armaments and } \\
\text { military equipment } \\
\text { of the Armed } \\
\text { Forces of Ukraine }\end{array}$ & R6 & 6328904,8 & 15925513,1 & 431493,2 & 16357006,3 & 0,03 \\
\hline $\begin{array}{l}\text { Construction (pur- } \\
\text { chase) of housing } \\
\text { for the Armed } \\
\text { Forces of Ukraine } \\
\text { servicemen }\end{array}$ & R5 & 751022,3 & 826200,0 & 31401,1 & 857601,1 & 0,04 \\
\hline $\begin{array}{l}\text { Disposal of am- } \\
\text { munition, rocket } \\
\text { fuel liquid compo- } \\
\text { nents, arma- } \\
\text { ments, military } \\
\text { equipment and } \\
\text { other military } \\
\text { property, ensuring } \\
\text { survivability and }\end{array}$ & R3 & 140827,4 & 309500,0 & 24719,1 & 334219,1 & 0,08 \\
\hline
\end{tabular}



of Ukraine Development Programs in Compliance with NATO Standards

\begin{tabular}{|l|l|l|l|l|l|l|}
\hline \hline $\begin{array}{c}\text { Name in accor- } \\
\text { dance with de- } \\
\text { partmental and } \\
\text { program classifi- } \\
\text { cation of expendi- } \\
\text { tures and credits } \\
\text { of the state } \\
\text { budget }\end{array}$ & $\begin{array}{c}\text { Total, } \\
\text { Ths. UAH }\end{array}$ & $\begin{array}{c}\text { Total, } \\
\text { ths. UAH }\end{array}$ & $\begin{array}{c}\text { General } \\
\text { fund } \\
\text { ths. UAH }\end{array}$ & $\begin{array}{c}2018 \\
\text { Special } \\
\text { fund } \\
\text { ths. UAH }\end{array}$ & $\begin{array}{c}\text { Total, } \\
\text { Total } \\
\text { ths. UAH }\end{array}$ & S \\
\hline $\begin{array}{l}\text { explosion and fire } \\
\text { protection of ar- } \\
\text { senals, bases and } \\
\text { warehouses of the } \\
\begin{array}{l}\text { Armed Forces of } \\
\text { Ukraine }\end{array}\end{array}$ & & & & & & \\
\hline $\begin{array}{l}\text { Implementation of } \\
\text { measures to in- } \\
\text { crease the de- } \\
\text { fense capability } \\
\text { and security of the } \\
\text { state }\end{array}$ & & 527900,0 & & & & \\
\hline
\end{tabular}

Therefore, the search results for appropriate solutions for the allocation and use of budget funds for the Armed Forces of Ukraine development programs under the conditions of economic instability based on the AFU functioning within the limits of use of budgetary and borrowed funds, taking into account the critical consequences aimed at maximizing the utility function, are presented in Table 5:

Table 5

Allocation of budgetary and borrowed funds according to NATO standards and critical consequences aimed at maximizing the utility function

\begin{tabular}{|c|c|c|c|c|c|}
\hline $\begin{array}{c}\text { The AFU } \\
\text { develop- } \\
\text { ment pro- } \\
\text { grams }\end{array}$ & $\begin{array}{c}\text { Funds alloca- } \\
\text { tion due to } \\
\text { programs, } \\
\text { ths. UAH }\end{array}$ & $\begin{array}{c}\text { Percentage of } \\
\text { allocation by } \\
\text { programs }\end{array}$ & $\begin{array}{c}\text { NATO } \\
\text { Stan- } \\
\text { dard }\end{array}$ & $\begin{array}{c}\text { Min- } \\
2017\end{array}$ & $\begin{array}{c}\text { Development } \\
\text { scenario in- } \\
\text { dicators, } \\
\text { ths. UAH }\end{array}$ \\
\hline$x_{1}$ & 61200 & $72 \%$ & $40 \%$ & 52000 & 67320 \\
\hline$x_{2}$ & 2975 & $3,50 \%$ & $20 \%$ & 2100 & 3867,5 \\
\hline$x_{3}$ & 850 & $1 \%$ & $2 \%$ & 140 & 850 \\
\hline$x_{4}$ & 2550 & $3 \%$ & $3 \%$ & 1900 & 2550 \\
\hline$x_{5}$ & 425 & $0,50 \%$ & $5 \%$ & 350 & 425 \\
\hline$x_{6}$ & 17000 & $20 \%$ & $30 \%$ & 6300 & 22100 \\
\hline
\end{tabular}


Search results for the best allocation and use of budget funds for the Armed Forces of Ukraine development programs are presented in Table 6.

Table 6

Allocation and use of budget and borrowed funds for the AFU development programs on the basis of utility function

\begin{tabular}{|l|c|c|c|c|c|c|c|}
\hline & $F u$. & $X_{1}$ & $X_{2}$ & $X_{3}$ & $X_{4}$ & $X_{5}$ & $X_{6}$ \\
\hline Prior to optimization & 216,8 & 52000 & 2100 & 140 & 1900 & 350 & 6300 \\
\hline After optimization & 362,2 & 57050 & 2100 & 850 & 2250 & 350 & 22100 \\
\hline
\end{tabular}

According to the results achieved, the Ministry of Defense of Ukraine received a tool and mechanism for finding appropriate solutions, based on the estimation of the expected execution of the main budget of the Armed Forces of Ukraine for expenditures and is presented by scenarios as pessimistic, most probable and optimistic, considering the possible consequences of its under expenditures and increasing the effectiveness of its use.

Optimization of the Armed Forces of Ukraine budgeting process confirms that it is the probability of budget execution, its focus on preventing the flexibility of military doctrine in the context of hostilities and respect of NATO standards when allocating funds for the programs that significantly contribute to the finding of the most guaranteed choice of funding for the main AFU programs. This is the overall economic and military defense effectiveness of the decisions taken.

Optimization of the AFU programs budget funds allocation does not mean that we take into account the influence of interaction between the planning and the AFU budget execution indicators on the effectiveness of defense reform in Ukraine. This process is greatly influenced by the human and collective factors. Therefore, this process should be considered as cognitive, where the psychological and mental capabilities of the defense sector can effectively perceive the environment and make appropriate decisions on the path to defense reform.

In order to find out which factors exactly or the interaction of factors especially affect the defense sector reform, let's make a cognitive model based on the following factors:

1 - effectiveness of defense reform in Ukraine aimed at increasing military competitiveness and protection of the territory of the state from aggressor; 
472 V a s y I P r o k n y a, O I e s a nd r o s t a p e nk o

Model of Allocation of Budget and Borrowed Funds for the Armed Forces of Ukraine Development Programs in Compliance with NATO Standards

2 - ratio of the special budget fund to the general one, which affects the economic and financial activities of the Armed Forces of Ukraine by types of implementation of the defense capabilities development programs;

3 - reduction of the AFU budget underfunding in accordance with departmental and program classification of expenditures and crediting of the state budget

4 - deviation of actual indicators of the AFU budget execution according to the departmental and program classification of expenditures and crediting of the state budget;

5 - reduction of the AFU planned budget targets deviation in accordance with the departmental and program classification of expenditures and crediting of the state budget from NATO standards;

6 - increase of loan commitments under the programs without significant stabilizing financial resources;

7 - increase in the slowdown of the AFU armament and military equipment development at the expense of inefficient use of budget funds;

8 - state organizational and financial support of the state's stock structures aimed at profitability and competitiveness of the main enterprises of militaryindustrial complex on the world market; coalition.

9 - effectiveness of military assistance from the countries of the friendly

The effectiveness of the contours formed as an oriented graph models is established by the formalization of the causal connections between the factors of the fuzzy cognitive model characterizing the effectiveness of defense reform in Ukraine. The contours can be effective and ineffective, respectively stabilizing or enhancing, as well as stimulating or disincentive.

The cognitive model of the impact of interaction between the planning and the AFU budget process execution indicators on the effectiveness of defense reform in Ukraine establishes the links in the contours of the defense reform effectiveness management, which can be defined as critical, i.e.risky and provides an opportunity to assess the risk levels of each contour and to model scenarios and options for improving the processes of planning and use of budget funds for defense reform.

For the visual perception of the cognitive model structure we use the oriented graph of this model, as presented in Figure 4. 
Figure 4

An oriented graph of the cognitive effectiveness of the defense reform in Ukraine

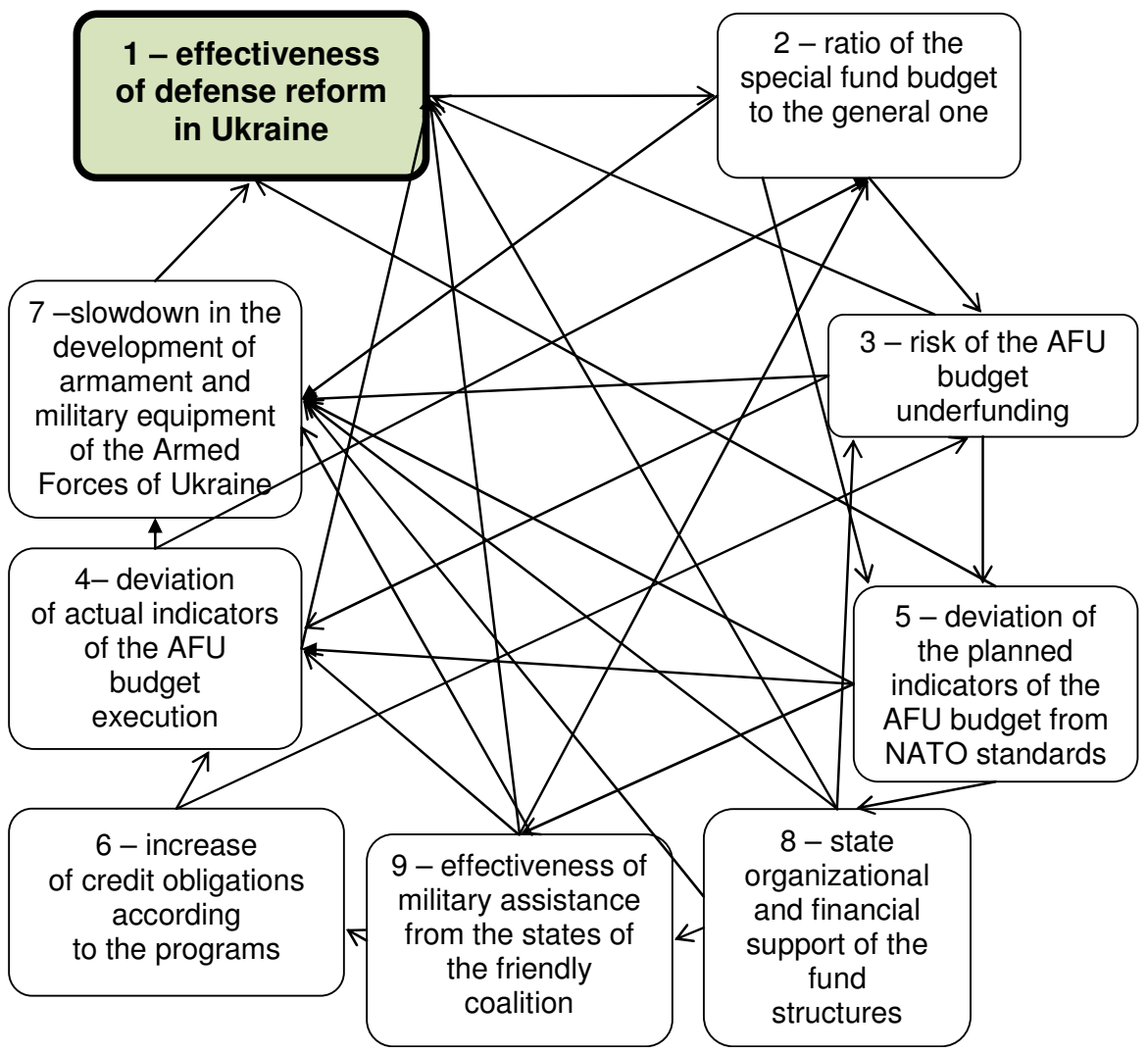

In order to study the dynamics of influence of the factors 2, 3, 6 and 9, acting as instruments of the AFU budget resources management on the target vertex 1 , we apply the method of impulse processes. This method is used for scenario modeling of alternative decisions.

Figure 5 presents the dynamics of changes and impacts of vertices 2 and 3 on the target vertex 1 . 
474 V a s y I P o r o k n y a, O I e k a n d r O s t a p e nk o Model of Allocation of Budget and Borrowed Funds for the Armed Forces of Ukraine Development Programs in Compliance with NATO Standards

Figure 5

Dynamics of the impact of vertices 2 and 3 impulses on the target vertex 1

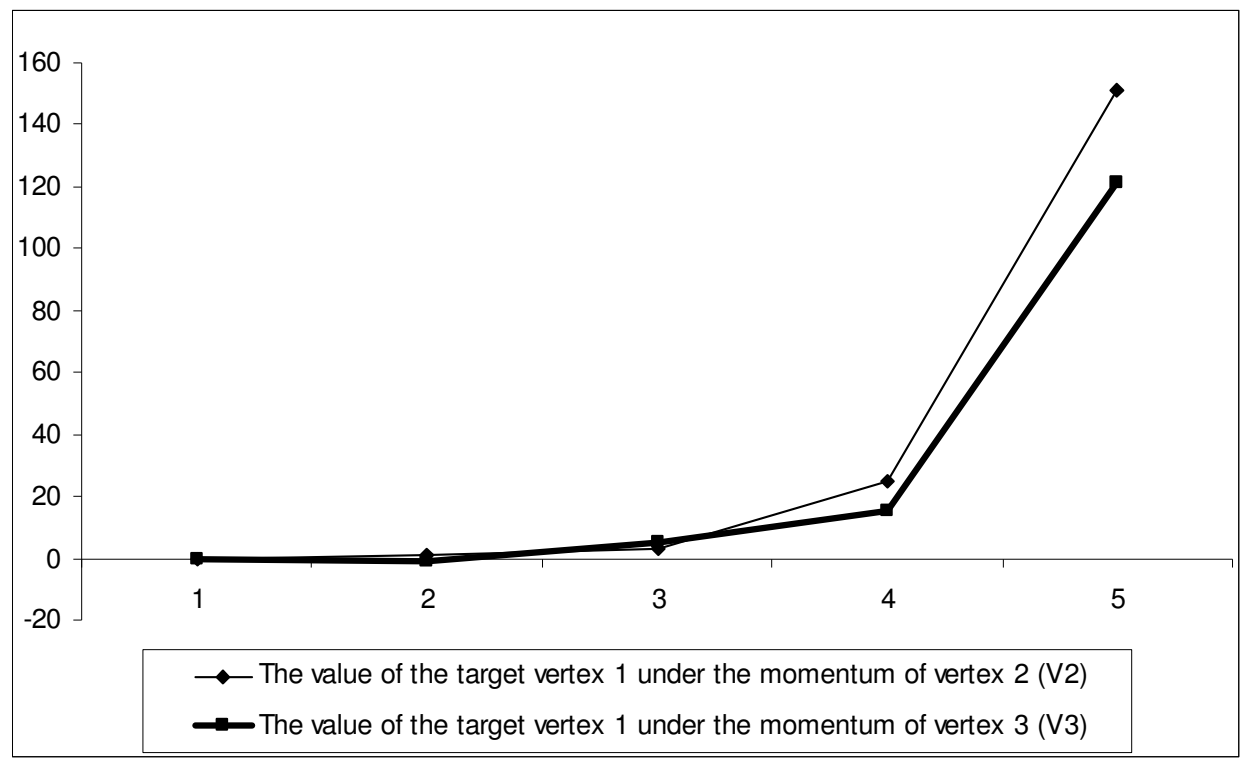

The decrease of the Armed Forces of Ukraine budget underfunding initially leads to a vibrational process of impacts on the target vertex, but then the process stabilizes. As regards the impact of the vertex 2 (the ratio of the special fund budget to the general one) on the target vertex, the process has some fluctuation at the beginning of the process, which consequently leads to a positive increase of this impact on the effectiveness of the Armed Forces of Ukraine reform.

Figure 6 presents the dynamics of changes and impacts of vertices 6 and 9 on the target vertex 1.

Regarding the influence of the vertices 6 and 9 impulses on the target vertex 1 , it has a dynamic rise character, but the vertex 9 has somewhat fluctuating form, which confirms the proportional connection between the effectiveness of the AFU reforms and the effectiveness of military assistance from the states of the friendly coalition. 
Figure 6

Dynamics of the influence of vertices 6 and 9 impulses on the target vertex 1

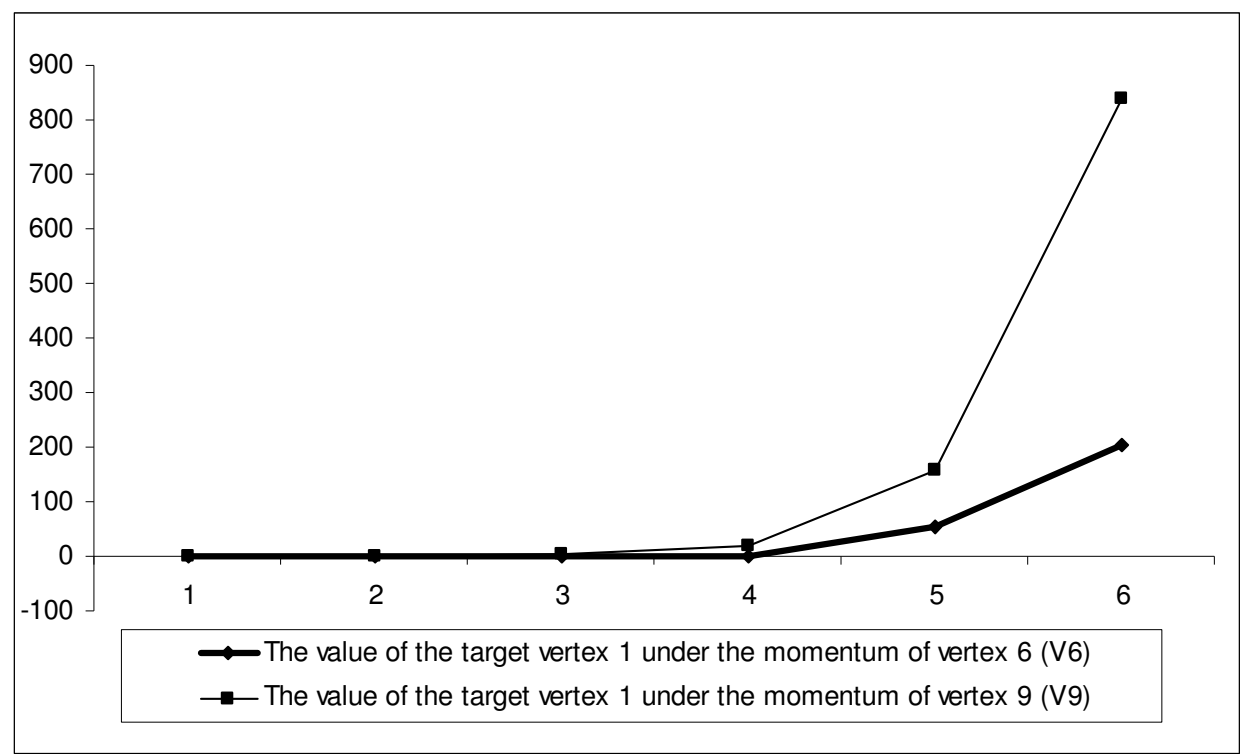

\section{Conclusions}

The result of the evaluation of the Armed Forces of Ukraine effectiveness based on the utility function and cognitive model was the management model for the processes of budget and borrowed funds use for the AFU development programs in compliance with NATO standards. The model takes into account the long-term programs development levels and the probability of their implementation, affecting the interaction between the indicators of the AFU planning and budget process execution and increasing the effectiveness of defense reform in Ukraine. Its practical use helps to approach NATO standards in budgetary sphere and provides an opportunity to forecast budget under expenditures under the risk of its use. 


\section{References}

1. Bulhakova, S. (2010). Budgetary risk: essence, classification, risk factors // Visnyk KNTEU. No. 1. - pp. 59-68. (In Ukrainian).

2. Bulhakova, S., Mykytiuk, I. (2010). Budgetary risks management, Visnyk KNTEU. No. 2. - pp. 78-88. (In Ukrainian).

3. Fedosov, V. M. (2012). Budgetary system: textbook / edited by V. M. Fedosov, S. I. Yurii. K.: Center of educational literature; Ternopil : Econ. Dumka, 871 p. (In Ukrainian).

4. Vitlinskii, V. V., (2004). Riskology in economics and entrepreneurship: Monography / V. V. Vitlinskii, H. I.Velykoivanenko. K.: KNEU, 480 p.

5. Donets, L. I. (2006). Economic risks and methods of their measuring: Textbook / L. I. Donets. K.: Center of educational literature, $312 \mathrm{p}$.

6. Sovietova, K. O. (2012). The essence of risk as an economic category. Business inform. - No. 3. pp. 12-16.

7. Sovietova, K. O. (2012). The essence of risk as an economic category. Business inform. No. 3. pp. 12-16.

8. Sahaniuk, F. V., Kovalenko, V. A., Holubieva, O. M. (2013). Views on the establishment of an integrated risk management system for long-term defense planning/ Collection of scientific works of the Center for military-strategic researches of the National University of Defense of Ukraine.-K.: No. 2(48), pp. 108-113.

9. Order of the Ministry of Defense of Ukraine No. 610 dated November 17, 2016 "On Approval of the Provision on Mid-Term and Short-Term Defense Planning in the Ministry of Defense of Ukraine and the Armed Forces of Ukraine»

10. Dejan Stojkovic, Bjørn Robert Dahl (28 February 2007). Methodology for long term defense planningNorwegian Defense Research Establishment (FFI), 46p. Retrieved from: https://www.ffi.no/no/Rapporter/07-00600.pdf. 